\section{Tourism in contemporary cities: 6th ITSA Biennial Conference}

This special section of the International Journal of Tourism Cities (IJTC) has been compiled following the 6th Biennial Conference of the International Tourism Studies Association (ITSA), held at the University of Greenwich, London, England from 17 to 19 August 2016. This was the first time that the conference had been held in Europe and it provided an opportunity to meet, hear from and network with tourism scholars and professionals from across Europe, Africa, Asia, Australasia and North and South America. ITSA has a mission to encourage interaction and cooperation between scholars from developing and developed countries and the conference was successful in attracting around 200 delegates from 29 countries. The theme of the conference was "Tourism in contemporary cities". Within this broad theme, four sub-themes were included: "Tourism cities and urban tourism", "The Chinese market for European tourism", "River, cruise and maritime tourism" and "Heritage tourism in cities". The sub-themes were chosen to reflect the unique location of the conference on the UNESCO Maritime Greenwich World Heritage Site, and London which is Europe's most visited tourist destination (Euromonitor, 2017). During the conference, two special sessions on "dark tourism and cities" and "tourism and communist heritage" were also presented, which have led to additional special issues of the IJTC.

Five invited keynote speakers presented during the conference, on topics related to the theme of tourism and contemporary cities:

1. Professor Cara Aitchison, Vice Chancellor of Cardiff Metropolitan University: "From events management to cultural diplomacy: creating a virtuous cycle of economic growth, social cohesion and international cooperation through hosting major events".

2. Dr Perunjodi Naidoo, University of Technology, Mauritius: "Resort tourism and the Chinese market".

3. Allan Brodie, Senior Investigator Historic England: "Steamers, rivers and the origins of popular tourism in England".

4. Professor Alexis Papathanassis, Bremerhaven University of Applied Sciences Germany: "High hopes \& high seas: the role and impact of cruise tourism in destination management".

5. Professor Jon Wilson, Halal Tourism Officer for Indonesian Ministry for Tourism: "Insights into Halal Tourism and global urban millennials".

One of the key aims of the ITSA is to encourage collaboration and exchange between researchers from developed and emerging economies. The papers included in this special issue represent the wide geographical and subject range of papers presented at the conference, by both established academics and emerging scholars. This special issue is themed around "Tourism and contemporary cities".

City destinations are central to contemporary tourism. In 2016, according to the United Nations, more than 54 per cent of the world's population lived in urban environments and this is projected to grow to 60 per cent by 2030 (United Nations, Department of Economic and Social Affairs, 2016). The rapid growth of global cities has been mirrored by the growth in tourism to these destinations and understanding this phenomenon is vital in ensuring the developments associated with urban tourism are sustainable and local urban populations both benefit from the industry and support it (see Novy and Colomb, 2017). Many cities are gateways for tourists visiting a country, whilst the world's most important tourism cities are destinations in their own right. Secondary cities - or intermediate cities (Marais et al., 2016) - in a country are also (c) International Tourism Studies Association

This paper forms part of a special section on "Tourism in contemporary cities". 
beginning to develop their offer and promote themselves as tourist destinations, seeking to capitalise on the new economic opportunities linked with lucrative global tourism flows. This is often part of government strategy to move tourist flows away from the primary cities in an attempt to reduce problems associated with overtourism, and to redistribute the benefits that tourism brings - see for instance the UK Government's Tourism Policy in 2011 which aimed to use the hosting of the Olympic Games 2012 as a way of creating and promoting alternative destinations to match London (DCMS, 2011; Kennell and Chaperon, 2013).

The collection of papers in this special issue reflects the diversity of contemporary city tourism destinations, with studies measuring and analysing tourist motivations, levels of tourist satisfaction and perceptions of tourist destination image. The case studies are based on cities as distinct as Ljubljana, the small European capital of Slovenia with a population of around 280,000, to Lagos the capital of Nigeria and a global megacity with a population of more than 20 million. In addition, case studies are presented on the major beach resort cities of Nha Trang in Vietnam and Balneario Camboriu in Brazil, as well as the Nigerian regional cities of ljebu-Ode and lle-Ife.

Starting with tourist motivations, Bozic et al. analyse the major pull factors for tourists visiting the capital of Slovenia, Ljubljana. Their results show that the most significant pull factor for visits to Ljubljana is the cultural characteristics of the destination, followed by the attractiveness of the entertainment and nightlife offer. The authors use the analytic hierarchy process, a method that is gaining popularity in tourism studies which combines quantitative data from the more common choice ranking systems with qualitative data in the form of verbal responses to the same criteria, producing richer data for a more exploratory approach (Saaty, 1980; Wang et al., 2016). This combined method is particularly valuable for exploring tourist motivations to city destinations where the product offer, and associated range of pull factors, can be extremely broad and where ranking preferences is complex.

Tourist motivations are also investigated by Aqbabiaka, Omisore and Odunsi in their paper on medical tourism in Lagos, Nigeria, though in this context a combination of both push and pull factors are considered. Travelling away from one's usual place of residence in search of medical treatment is a growing trend that merges holidaymaker and patient, and is especially common in urban areas. Most research has been carried out about international medical tourism, with people travelling across borders (usually from developed to developing countries) seeking shorter waiting times and more affordable healthcare (Connell, 2011), but despite being a $\$ 100$ billion industry, little is known about the key drivers for it (Fetscherin and Stephano, 2016). Unusually, Aqbabiaka et al.'s paper focusses on domestic medical tourism, examining the motivations and experiences of patients at both public and private hospitals in Lagos. The findings from patients at the public hospitals provide useful recommendations for the Lagos Ministry for Health in terms of identifying shortcomings and potential push factors for medical tourism, whilst the responses from patients in the private hospitals contributes to our understanding of the motivations for their visit as well as their levels of satisfaction with the medical tourism product on offer.

The paper authored by Aqbabiaka in this collection also looks at motivations but this time in relation to traditional cultural festivals in two smaller cities, ljebu-Ode and lle-lfe, about $150 \mathrm{~km}$ outside of Lagos. Previous research into motivations for event attendance has drawn strongly on the tourism literature (Hawkes et al., 2016). In this paper, various practical factors are deemed influential, such as the event facilities, infrastructure and accommodation, but the overriding motivation for attending the events is found to be for leisure purposes, and mainly for the opportunity to socialise with friends. Using social exchange theory (see Nunkoo, 2016), the author also examines how local residents perceive the impacts of the events and recommends that the relevant local authorities oversee and coordinate the festival activities in order to improve their sustainable development.

The fourth and fifth papers in this collection are about coastal cities, providing us with a different city tourism context. The first of these two papers by Le is about the factors affecting satisfaction levels amongst European tourists to Nha Trang. This coastal city in Vietnam is most popular for its beaches and its scuba diving offer, attracting more than one million international tourists per year, but the destination has recently experienced a decline in the number of European tourists. Using quantitative surveys and structural equation modelling, this paper aims to explain this downturn by examining the most significant factors affecting tourists' satisfaction. It is often assumed that destination attributes such as accommodation, food, retail and both natural and man-made

PAGE 322 INTERNATIONAL JOURNAL OF TOURISM CITIES $\mid$ VOL. 3 NO. 42017 
attractions are the most significant factors affecting visitor satisfaction, but lessons can be learnt from the findings of this study in that they reveal the most important factor to be the friendliness and hospitality of the local people (see also Nilplub et al., 2016). Based on this finding, practical recommendations are made to the city's government to build on this strength by increasing awareness amongst local residents of the benefits of tourism development in their neighbourhoods and to develop activities which help local residents to maintain this positive perception for a sustainable tourism industry in the future.

The final paper in this collection is by Anjos, Pereira and Tennenberg and it presents a quantitative analysis of destination image formation, examining the cognitive, affective and conative image components - that is, perceptions people have of the destination based on the information available, their more deeply encoded attitudes towards the destination and the relationship they have with it, and their actions taken (Yuksel et al., 2010). The urban coastal resort of Balneario Camboriu in Brazil is used as a case study and the results demonstrate the direct link between cognitive and affective components with the conative outcomes.

Taken together, these papers reflect the diversity in the membership of ITSA and in the attendance at the 6th Biennial Conference. As ITSA continues to develop its international reach, these papers present an excellent introduction to the work of this growing association for tourism scholars.

\section{References}

Connell, J. (2011), "A new inequality? Privatisation, urban bias, migration and medical tourism", Asia Pacific Viewpoint, Vol. 52 No. 3, pp. 260-71.

DCMS (2011), "Government Tourism Policy”, Department for Culture Media and Sport, London.

Euromonitor (2017), Top 100 City Destinations Ranking, Euromonitor, London.

Fetscherin, M. and Stephano, R.-M. (2016), “The Medical Tourism Index: scale development and validation”, Tourism Management, Vol. 52, pp. 539-56.

Hawkes, D., Kennell, J., Booth, P. and Abson, E. (2016), "The impact of motivation factors on spending at a public sector festivals programme”, in Matias, A., Nijkamp, P. and Romao, J. (Eds), Socio-Economic Impacts of Tourism, Springer, Geneva, pp. 67-80.

Kennell, J. and Chaperon, S. (2013), "Analysis of the UK Government's 2011 tourism policy”, Cultural Trends, Vol. 22 Nos 3/4, pp. 278-84.

Marais, L., Nel, E. and Donaldson, R. (Eds) (2016), Secondary Cities and Development, Routledge, London.

Nilplub, C., Khang, D.B. and Krairit, D. (2016), "Determinants of destination loyalty and the mediating role of tourist satisfaction”, Tourism Analysis, Vol. 21 Nos 2/3, pp. 221-36.

Novy, J. and Colomb, C. (2017), "Urban tourism and its discontents: an introduction", in Colomb, C. and Novy, J. (Eds), Protest and Resistance in the Tourist City, Routledge, London.

Nunkoo, R. (2016), "Toward a more comprehensive use of social exchange theory to study residents' attitudes to tourism", Procedia Economic and Finance, Vol. 39, pp. 588-96.

Saaty, T. (1980), The Analytic Hierarchy Process: Planning, Priority Setting, Resource Allocation, McGraw-Hill, New York, NY.

United Nations, Department of Economic and Social Affairs (2016), The World's Cities in 2016 - Data Booklet (ST/ESA/SER.A/392), United Nations, Geneva.

Wang, X., Li, X., Zhen, F. and Zhang, J. (2016), "How smart is your tourist attraction? Measuring tourist preferences of smart tourism attractions via a FCEM-AHO and IPA approach", Tourism Management, Vol. 54, pp. 309-20.

Yuksel, A., Yuksel, F. and Bilim, Y. (2010), "Destination attachment: effects on customer satisfaction and cognitive, affective and conative loyalty", Tourism Management, Vol. 31, pp. 274-84.

\section{Further reading}

ITSA (2017), "Why ITSA?", available at: http://intltourismstudies.com/why-itsa/ (accessed 16 October 2017). 